\title{
Delicadas coreografias
}

As imagens que compõem esta edição da revista Interface fazem parte da tese de Doutorado de Flavia Liberman, que originou o livro "Delicadas coreografias: instantâneos de uma terapia ocupacional" (São Paulo: Summus Editorial, 2008). Elas captam corpos, abordagens corporais e dança em diferentes contextos: coordenação de grupos com diferentes populações e docência em disciplinas de Atividades e Recursos Terapêuticos em cursos de graduação em Terapia Ocupacional. O trabalho clínico e docente é de Flávia Liberman e o olhar sensível das fotografias, de João Caldas.

João Caldas é paulista, paulistano, fotógrafo, 52 anos, casado, dois filhos. Formado em Engenharia (FAAP-82) e Cinema (ECA-82), em 1982 realizou os primeiros trabalhos para teatro e dança como fotógrafo autônomo para o IDART (Departamento de Informação e Documentação Artística - criado pela Secretaria Municipal da Cultura de São Paulo). Em seguida foi contratado como fotógrafo do Centro Cultural São Paulo, Divisão de Pesquisas de Artes Cênicas, realizando trabalhos de documentação de teatro, dança e artes plásticas.

Entre 1985 e 1987 foi contratado pela Folha de São Paulo como repórter fotográfico. Após esta importante experiência profissional, montou o Formato Estúdio, produzindo fotos para catálogos, folhetos, anúncios e prestando assessoria de imprensa na área empresarial.

Mas foram os trabalhos fotográficos nas artes cênicas, principalmente teatro, que se tornaram sua principal atividade profissional. Tem acompanhado regularmente a cena paulistana nos últimos 28 anos fotografando para inúmeros grupos, atores, produtores e diretores de teatro.

O fotógrafo colaborou com o Arquivo Multimeios do Centro Cultural São Paulo, fez trabalhos para o Teatro Popular do Sesi e fotografa regularmente para o Teatro Escola Célia Helena, Casa do Teatro e Teatro Imprensa. Fotografou os últimos musicais montados em São Paulo pela CIE Brasil (hoje Time4fun) e os musicais dirigidos por Jorge Takla.

Na área de dança, fotografa trabalhos de Célia Gouvêa, Marta Soares e Emilie Sugai. Entre 2002 e 2004 fotografou para o Dança em Pauta, do Centro Cultural Banco do Brasil e, atualmente, trabalha para a São Paulo Companhia de Dança. 


\section{SOBRE AS FOTOS}

série Tocar (2003) e série Gesto (2003)

Workshop de Danceability, no curso de graduação de Terapia Ocupacional da Universidade de São Paulo, coordenado por Flavia Liberman, pela terapeuta ocupacional Marisa Samea e pela arte-educadora alemã Barbara Von Trote.

série Pés (2006) e série Movimentos (2006)

Grupo de Estudos de Corpo e prática clínica com estudantes e profissionais terapeutas ocupacionais.

série Pinturas (2003)

Grupo de mulheres do Bairro dos Morros/Sorocaba, Disciplina de Prática Profissional no curso de graduação de Terapia Ocupacional da Universidade de Sorocaba.

série Folias (2003)

Grupo de dança e abordagens corporais composto por mães e acompanhantes de crianças e adolescentes da Estação Especial da Lapa (EEL), Fundo Social de Solidariedade, São Paulo.

série Quebra-cabeças (2006), série Olhar (2006), série Mãos (2003 e 2006)

Disciplinas de Atividade e Recursos Terapêuticos no curso de graduação em Terapia Ocupacional, Centro Universitário São Camilo, São Paulo. 